\title{
A Group of Indonesian Adult EFL Students' Mastery of Tenses and Aspects: Investigating the Internal and External Factors of Learning
}

\author{
Muhlisin (Corresponding author) \\ Faculty of Teacher Training and Education, University of Muhammadiyah Jember, \\ Jl. Karimata No 49, Jember, East Java, Indonesia \\ E-mail: muhlisin@unmuhjember.ac.id \\ Hairus Salikin \\ English Department, Faculty of Letters, University of Jember \\ Jl. Kalimantan 37, Jember, Jember, East Java, Indonesia \\ E-mail: hairussalikin@yahoo.com
}

Doi:10.7575/aiac.alls.v.6n.5p.143

URL: http://dx.doi.org/10.7575/aiac.alls.v.6n.5p.143
Received: 08/05/2015

Accepted: 25/07/2015

The study was supported and fully funded by University of Muhammadiyah Jember.

\begin{abstract}
The study aimed, firstly, to assess a group of Indonesian adult EFL students' mastery of tenses and aspects as part of their mastery of English grammar and, secondly, to identify if their experience of going through the instructional processes, their perceptions of and habits in studying English grammar shaped their mastery of tenses and aspects. The data were collected through a grammar test and a semi-structured interview. As the study was conducted, the students were sitting in the fourth (last) year of their study. Despite having such long instructional experience, however, the findings show that the mastery of tenses and aspects of majority of the students still fell into the "fail" category. Also, their having perception that studying English grammar is important apparently did not shape their mastery of tenses and aspects. What seemed influential as to shaping their mastery was much more related to their habits in studying, the modes of instruction they experienced, and the type of language samples they were exposed to, especially during the process of receiving grammar instruction in the classroom.
\end{abstract}

Keywords: grammatical competence, mastery of tenses and aspects, English as a foreign language

\section{Introduction}

Grammatical competence constitutes one of the four competences which support the development of communicative competence in learning a second and foreign language (Canale \& Swain, 1980; Canale, 1983). The other kinds of competence, according to Canale and Swain (1980) and Canale (1983), include sociolinguistic, strategic, and discourse competence. Hence, developing grammatical competence is important for both second and foreign language learners, for such competence can help them develop skills in using the target language more fully. In regard to speaking and writing skills, for instance, grammatical competence enables the learners to construct words into meaningful sentences or utterances. Meanwhile, in regard to listening and reading skills, grammatical competence enables the learners to decode sentences or utterances. The main aim of teaching and learning grammar, therefore, should be to help the learners understand and use the target language accurately and appropriately in communicative contexts.

Where foreign language teaching and learning are concerned, the development of grammatical competence of the learners seems to have strong reliance on the classroom teaching and learning process. From the teaching perspective, in order that foreign language learners develop their grammatical competence in the target language, the easier and probably also the more effective way would be by teaching grammatical structures of the target language in a set of communicative discourse. Meanwhile, from the learning perspective, in order that the learners are able to develop grammatical competence, they need to be attentive to what is taught by the teacher and to also actively engage in learning activities that go beyond the constraints of the classroom.

Although in some informal communicative contexts, grammar-free communication might be deemed acceptable as far as the interactants can understand each other. In formal communicative contexts, on the other hand, the ability to use language both accurately and appropriately is highly expected. In that case, attaining ample proficiency in learning a second and foreign language would ultimately also calls for mastery of grammatical competence as well. Otherwise, the learners would confront a number of problems or difficulties, especially when they are expected to communicate using the target language with a high degree of accuracy and preciseness. So, in the process of teaching and learning a second 
and foreign language, all aspects that are related to the target language should be thoroughly covered. None of the aspects is worth setting aside, including grammar of the target language.

As far as learning English grammar is concerned, tenses and aspects may be regarded as one of the most essential parts to master by the learners. One reason is because tenses and aspects deal particularly with how particular sentences or utterances are constructed with regard to the time as to when the events being stated take place. Also, tenses and aspects are of paramount importance to master wherever the learners are to grasp and be able to use other grammatical structures, like voices, tag formations, conditional constructions, etc. In other words, there are a number of structures of sentences or utterances in English language which strongly deal with the use of tenses and aspects. Thus, it would be very difficult for the learners to grasp and be able to use the structures without firstly have sufficient mastery of tenses and aspects.

For those studying in ELT program and intend to be an English teacher, having the ability to use English in any of the four domains only (listening, speaking, reading, and writing) might prove inadequate, especially when their students encounter a sort of linguistic problems which require them to explain what is and what is not possible in English sentences or utterances. As such, grammatical knowledge will help them and thus their students as well cope with the language more easily (Andrews, 1997, 2003; Hughes \& McCarthy, 1998; Shulman, 1987). In fact, such condition is, in many cases, inevitable.

Now that it is important for the students studying in ELT program and those intending to be an English teacher to learn English grammar as part of their pedagogical competence, not to say that it is also important as to developing their own grammatical competence as well, the current study therefore was aimed, firstly, to assess a group of Indonesian adult EFL students' mastery of tenses and aspects as part of their grammar mastery and, secondly, to identify if their experience of going through the instructional processes, their perceptions of and habits in studying English grammar shape their mastery of tenses and aspects.

The students involved in the study were purposively selected. It included the students of a four year undergraduate English language teaching program at one of higher educational institutions based in East Java, Indonesia. As the study was conducted, the students were sitting in the fourth (last) year of their study. The students, therefore, must have had ample experience of going through the processes of English language instruction.

\section{Literature Review}

\subsection{Traditional Linguistic Perspective on Second and Foreign Language Learning}

Linguistic theories provide a number of different theoretical frameworks as to explaining the gradual development of grammatical competence in learning a second and foreign language. One of the theories, for instance, claims that one of the most influential factors which facilitates or interferes with second and foreign language learning is the similarities and differences between the first language of the learners and the target language. Such a claim dates back to the structuralist era during 1950s and perhaps was most obviously enunciated by Lado (1957) and has been known as Contrastive Analysis Hypothesis (CAH) since then. With regard to this claim, Indonesian EFL students would definitely confront a great number of difficulties or interference in learning tenses and aspects of English grammatical structures, for no equivalence of such grammatical structures can be found in the students' first language.

Notwithstanding, however straightforward the claim posed by contrastive analysts as to predicting the area which will cause difficulties and that which will facilitate learning, studies in second and foreign language learning show that $\mathrm{CAH}$ still proves to be inadequate (e.g. Whitman \& Jackson, 2006). To some extent, however, the aspects related to linguistic and even cultural background of the learners might still need to be taken into account as one of factors influencing the learning process of a second or a foreign language. That is, the systems pertaining to the learners' first language might serve as the starting point for the learners as they embark on learning the systems of other languages (Odlin, 2003; Kellerman, 1995; Kellerman \& Sharwood-Smith, 1986). Also, Ringbom (2007) claims based on his research that:

The extent of congruence between grammatical categories is of special importance. When the L1 and L2 grammatical categories are largely congruent, the comprehension of lexical items (morphemes or words) is facilitated and the learner can approach the comprehension task without having to worry much about their syntactic relations (p. 68).

In that case, they might experiment if the systems pertaining to their first language are applicable to be generalised to the systems of the target language. Only when the learners are aware that they are not applicable, they might then shift into developing new systems pertaining to the target language.

As regards the system of tenses, at the very outset of learning, Indonesian EFL learners are very likely to experience confusion at the conceptual level which would affect their ability to employ the system in producing sentences or utterances in English. In fact, as Allen (1974, pp. 74-5) puts it, "[s]tudents who have been learning English for eighteen months or more are presumably already acquainted with the English tenses. It is however unlikely that they have any conception of the tense-scheme as a whole". Indeed, it is difficult for Indonesian EFL learners to attain a whole conception of tenses in English language in a short term. One reason is because tenses are quite conceptual. That is, it is not sufficient that the learners only know the grammatical forms of tenses, but they would also need to decipher the meaning and the functions of the forms in order to attain a whole conception of tenses and thus to be able to employ them accurately and appropriately wherever they produce sentences or utterances.

\subsection{Experiential Learning Model on Second and Foreign Language Learning}

Now that it can be argued that learning the system of tenses in English language for Indonesian EFL learners entails conceptual processing of information and not merely knowing grammatical forms of tenses, the process of learning 
which the learners need to undertake requires the processing of abstract information to be transformed into concrete application. To do this, the learners would need to engage in a cyclic process of learning where their exposure to linguistic patterns needs to be consciously analysed before being generalised to the relevant/similar contexts.

Kolb (1984) provides a quite illustrative theoretical description of such learning process known as 'experiential learning' model. According to the model, learning process is seen as "a process of resolution of conflicts between two dialectically opposed dimensions, called the prehension and transformation dimensions" (Kohonen, 1992, p. 16). The prehension dimension deals with how learners grasp their experience, while transformation dimension deals with any attempts to employ the experience for the performance. Furthermore, the two dimensions also "yield four orientations to learning" (ibid.), namely: concrete experience, reflective observation, abstract conceptualisation, and active experimentation.

As applied in learning the system of tenses, the learners having distinct grammatical system, for instance, may start from getting encounter to concrete experience of the use of tenses. Such encounter may take place in a variety of contexts where English sentences or utterances are actualised. In order that learning process takes place, the learners would then need to get engaged in reflective observation dealing with analysing forms, meaning and functions of the system as used in the variety of contexts from which they can then construct abstract conceptualisation about it through their logic and through employing systematic approaches to systematise the system as manifested in a variety of contexts. Once they are successful in constructing abstract conceptualisation, they would then be able to build fullfledged comprehension of the system.

Meanwhile, as a means to support their capability of using the system, they would also need to do active experimentation of using the system accurately and appropriately in a variety of contexts. Stemming from the stage of doing active experimentation, they can then see the responses or feedback from others, especially from those who are more proficient, from which they can get concrete experience again which can further be the input for their further reflective observation and abstract reconceptualisation and eventually also for their active reexperimentation. Thus, the learning process as seen from experiential learning model is cyclic in nature.

Different from the $\mathrm{CAH}$ perspective, the perspective from experiential learning model seems much more comprehensive as to explaining the process of successful learning for the learners having distinct grammatical system, for such learning requires the process of conceptualisation of concrete information concerning linguistic forms, meaning and functions. Thus, it can be argued, based on the experiential learning model, that the students who are successful in mastering the system of tenses in the study, despite the fact that no associated systems may be found in their first language, are the ones who have endeavoured to conceptualise the concrete information about the linguistic forms to make sense of them, especially with respect to their meaning and functions in a set of discourse.

\subsection{Tense}

With regard to the focus of the study, tense can be defined as "the grammatical expression of the location of events in time [which] anchors an event to the speaker's experience of the world by relating the event time to a point of reference" (Downing \& Locke, 2006, p. 352). Put it simply, tense deals with grammatical forms whose function is to relate the events manifested in speech to the time when the events take place. The definition, stated by Huddleston and Pullum (2005), seems even more specific. That is, "[a] tense system is a system associated with the verb where the basic contrasts in meaning have to do with the location in time of the situation, or the part of it under consideration" (p. 44).

Following the latter definition, it can be argued that the system of tenses refers to the system associated with forms of verb signifying the events of the speech to the time when they take place. Still, the association is not always straightforward (Huddleston \& Pullum, 2005, p. 44). For instance, the present progressive form of verbs is, by and large, used to refer to the events of speech being in the progress of speaking-e.g. I'm writing a letter now or she is having dinner. Yet, the same form can also be used to refer to the events to take place in the future-e.g. I'm leaving for Sydney tomorrow. Thus, it is worth noting that the system of tenses must not be associated with the time reference as to when particular events of speech take place.

Although it is usually stated in most textbooks of pedagogical grammar that there are as many as twelve tenses (e.g. Azar, 1992; Murphy 1989; Hewings, 1999), as seen from the most basic forms, however, it can be argued that there are only two types of tense in English language. As Downing and Locke (2006) put it:

English has just two tenses: the Present and the Past, as in goes/went, respectively. English has no verbal inflection to mark a future tense. The forms shall and will are not verbal inflections but modal auxiliaries which, when reduced, are attached to pronouns, not to the verb root (I'll wait outside). Also important are the form-meaning relationships. Shall and will belong to a set of modal auxiliaries and can express meanings other than reference to future time. (p. 353)

Stemming from what Downing and Locke have stated, it is quite obvious that the system of tenses only includes Present and Past, whereas shall and will, which are usually used to mark Future, do not, in particular, belong to the system of tenses, for shall and will are not derived from verb inflection whatsoever. Furthermore, "The choice of form [shall/will] depends on whether we are making a prediction about the future, expressing an intention, or talking about a plan for the future, and so on" (Eastwood, 1994, p. 95). In other words, shall and will also have other meaning and functions and thus are not limited to only mark futurity.

\subsection{Aspects}

Also strongly related to the system of tenses are aspects. In fact, aspects are the grammatical forms that make the specification of the events of speech and the time when the events take place even more specific. Hence, Downing and Locke (2006) state that, "[w]hile tense is used to locate events in time, aspect is concerned with the way in which the 
event is viewed with regard to such considerations as duration and completion when encoded by a verb. This is sometimes defined as "the internal temporal contour of the event" (Downing and Locke, 2006, pp. 369-370). Different from tenses, therefore, aspects deal more particularly with grammatical forms which relate the events of speech to the time span of which the events take place. The time span may be progressive/continuous ('for a period of time) or perfect ('up to now' or 'up to then') (Eastwood, 1994, p. 79).

\section{The Study}

The study was conducted at one of the universities based in East Java, Indonesia on the first semester of the 2014 academic year. In general, the study was conducted in four stages, namely: selecting and confirming the research participants, administering a test, conducting a semi-structured interview, and analysing both the results of the test and the responses to the interview.

\subsection{The Participants}

There were 55 participants in the study, all of whom were sitting at the last (fourth) year of their study at the English language teaching program of the university. The students, therefore, must have had ample experience of going through the processes of English language instructions.

\subsection{Instruments and Data Collection}

The instruments of the study included the use of a test consisting of 55 items and a semi-structured interview. The employment of the two different instruments was aimed to result in triangulated data, both quantitative data (as obtained from administering the test) and qualitative data (as obtained from conducting the semi-structured interview).

It is worth noting that prior to being used, the test had undergone the process of verification concerning their validity and reliability. The validity was established based on the validity of content. In so doing, the content was adjusted based on the comments from two experts in the field. As regards the reliability, the test was firstly tried out to a group of students, who are not the participants in the study, and the result of the try-out was analysed statistically using split-half formula to see the reliability. It was found that the reliability coefficient of the test is 0.85 .

\subsection{Semi-Structured Interview}

The aim of conducting a semi-structured interview was to get further in-depth data related to the data about the students' grammar mastery. In particular, the interview included questions about the participants' experiences of going through grammar instructions, their perceptions about learning English grammar (be it important or unimportant), and, especially to those perceiving that learning grammar is important, their habits in learning English grammar. The incorporation of the three major questions in the interview was aimed to shed light on the factors which might have shaped the participants' grammar mastery.

\subsection{Data Analysis}

As regards the data obtained from the test, each test score was compared with the grading scheme used at the institution. There are five ranges of the grading scheme, including Fail $(<50 \%)$, Pass (50\% - 64\%), Good (65\% - 74\%), Very Good $(75 \%-89 \%)$, Excellent $(90 \%-100 \%)$. Meanwhile, the data obtained from the interview were analysed through content analysis, i.e. regarding the participants' responses.

\section{Findings}

\subsection{Mastery of Tenses}

The data based on the students' scores on the test show that the majority of the students have not gained sufficient mastery of tenses and aspects. It was shown that 49 out of 55 students (89\%) got the score between 4 and 27 . On the basis the grading scheme use, the 49 students' mastery was categorised fail, i.e. their correct answers were less than $50 \%$ of the total questions given. The rest of the students fell into two categories: pass (five students) and very good (one student). The scores of the students with pass category ranged from 28 to 30, whereas the students with very good category scored 49 out of 55 . The distribution of the students' mastery is presented in Figure 1.

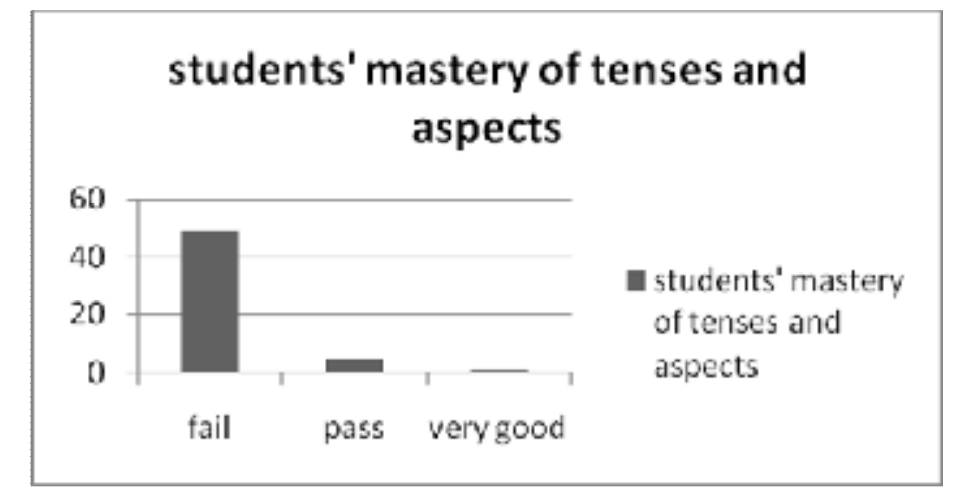

Figure 1. The percentage of the students' mastery of tenses and aspects

\subsection{Experiences of Going through English Grammar Instruction}

From the interview, it is known that the students encountered a wide range of instructional experiences of English grammar since high school. However, it is also known that the students were not very fond of the instructions they experienced. The modes of instruction as reported by the students are given in the table that follows. 
Table 1. The modes of English grammar instruction experienced by the students in high school and university

\begin{tabular}{cc}
\hline In high school & In university \\
\hline teachers' presentation of grammar rules & teachers' presentation of grammar rules \\
\hline drills & students' presentation \\
\hline grammar-focused translation & drills \\
\hline
\end{tabular}

\subsection{The Students' Perceptions of Studying Grammar}

Quite contradicted to the students' scores on their test results is that 50 out of 55 of them (90\%) reported that it was important to study grammar. In fact, some students contend that grammar mastery would help them speak and write better.

Response A: . . because when we speak or write when have to use grammar. When we produce ungrammatical language, others will not understand or hard to understand what we mean.

Response B: . . . no utterance or sentence is constructed in random. There are rules governing their constructions. When we know the rules, we'll be able to express what we mean properly. Grammar will also help us understand what native speakers speak or write.

Still, there are five students $(10 \%)$ who believe that studying grammar is not important. One of them even asserts that grammar is only a complement to formal discourse.

Response C: . . because as we speak, which is the most important skills in English, it is not important whether or not we speak grammatically correct. The most important is our interlocutor understands what we mean. Besides, grammar is only a complement to formal language. There are many people who are able to speak English not because they know grammar, but because they always try to speak, although they don't know grammar.

From the two quite contracting beliefs put forward by the students, it can be concluded that in general students claiming that it is important to study grammar believe that grammar will help them use and understand English more effectively, while those claiming that it is not important to study grammar believe that language is speech and that grammar does not relate to speech. Still, although there are as many as $50(90 \%)$ students claiming that it is important to study or know grammar, only one of them managed to get very good score in the test. Thus, it is necessary to further analyse the habits in learning of those 50 students, especially the very-good-scored one.

\section{4 The Habits in Studying Grammar}

As reported by the group of less successful students, there are five reasons which probably have made their learning outcomes are not that satisfying, including (1) low frequency of studying grammar, (2) got easily discouragedespecially when facing difficult grammar concepts, (3), failed to conceptualise grammar forms, meaning, and functions, (4) low reading habit. On the other hand, the one student who managed to be successful in coping with the test did conversely from what the group of less successful students did. Sample of the responses of the less successful group are given as follows:

Response D: ... I prefer studying English with my friends, practising conversation with them. ... I'm not really keen on reading.

Response E: . . . Sometimes. And when I do, I study the rules, try to understand them. Then I'll learn how to make sentences. But I get discouraged when the rules are too difficult.

Response F: . . I read the patterns, try to understand, sometimes I memorise them, then I'll do the exercises.

Response G: ... I learn the rules, memorise them, then make sentences.

\section{Discussion}

\subsection{The Learning Factors}

In any modes of learning, process is inevitable for outcomes. Learning process may be defined as any activities done in order to acquire, develop, and/or internalise information necessary for particular areas of knowledge or skills. Where second or foreign language learning is concerned, process plays significant role in shaping both competence and performance (Holec, 1981; Little, 1999, Oxford, 2008).

So, if the learners are not committed to the process, it will be hard for them to develop their potential, be it about developing knowledge or skills, in the target language. Apparently, this is one of the problems faced by most of the students involved in the study, despite their conscience that grammar is important. Also, since learning outcomes constitute "a cumulative effect on the development of the learners' cognitive and affective characteristics" (Kohonen, 1992, p. 15), the learning process the students go through must not only be temporary. However, it is important that the students engage in timely and timeless learning process; and thus the notion of lifelong learning thereof.

Of paramount importance in learning process is the conceptualisation of the information. The less successful students, however, seem are not fully engaged in this sort of information processing. That is, as seen from their responses, many 
of them concerned with memorisation of patterns or rules (forms). To gain fully fledged mastery of grammar, however, the students need to go beyond knowing linguistic forms only, but they would need to conceptualise the meaning of the forms and their functions as used in a set of discourse (Larsen-Freeman, 2001).

For the students to be able to conceptualise grammatical forms, meaning, and functions, it is important that they get ample input to the actual use of the target language. Such process may best be done through reading in the target language, for different from spoken discourse, written discourse provides the students with more salient features as to how grammatical elements are performed. Such salience can be very helpful for the students in order to raise their awareness to the area which they have not mastered yet. Still, following the experiential learning model, the students would need to get engaged in reflective observation as to analysing certain grammatical forms, meaning and functions realised in a set of discourse to build abstract conceptualisation and further to improve their prehension dimension of them. Otherwise, the salience would go unnoticed and thus would fail to contribute to their improved prehension dimension of the system related to the grammatical forms, meaning and functions. Indeed, there is one point of agreement among the researchers in the field that students need to attend to forms, meaning, and functions realised in a set of discourse in order to gain from meaningful grammar learning (Ellis, 2006; Celce-Murcia, 2002).

\subsection{The Instructional Factors}

Strongly related to the learning process is the instructional process. Good language instruction should be able to facilitate the growth of autonomous learning. One way to do so is to teach the students how to cope with their own learning. The sort of instruction, however, was absent. In fact, as revealed by the students (see Table 1), the instructions were mostly teacher-centred in which the teacher gave excessive explanations of rules and controlled practice (drills). Further, where controlled practice was concerned, it was mostly to practise rules in sentences that are from being contextual.

This sort of decontextualised grammar practice definitely failed to help the students internalise grammatical forms taught in the classroom. Indeed, one empirical evidence revealed by Lightbown (as cited in Lightbown and Spada, 1999, p. 120) shows that although the students taught under decontextualised grammar practice were able to maintain a high degree of accuracy on particular grammatical forms as the forms were taught in the classroom, as the teaching went on to other grammatical forms, however, the students' ability on the forms taught previously decreased and thus they were no longer able to maintain a high degree of accuracy in using the grammatical forms simply because the forms were no longer taught. Instead, their ability shifted to the new area of grammatical forms currently taught by the teacher. What is more, the students were not able to transform what they learned in the classroom into authentic communication outside of the classroom settings.

The other extreme form of instruction that the students experienced was totally student-centred in which they were totally held responsible for their own learning without getting any assistance from the teacher. Such a form of instruction was mostly encountered at the university where the students studied. As regards its implementation, the teacher asked the students to do presentation of particular grammar topics in groups. What is worst is that during the process of preparing their presentation, the students usually confronted a high degree of confusion but still hardly achieved any assistance from the teacher.

Both of the modes of instructions are very likely to be the factors shaping the students' failure, i.e. in addition to the students' less committed efforts on learning as well. Still, the students' being less committed or motivated in the learning might also have been caused by the instructions they experienced.

Based on constructivist theory, the ideal mode of instruction is the one that involves mutual cooperation between the teacher and students and amongst the students. According to the theory, the teacher must facilitate the students' learning by means of, for instance, providing learning prompts that are a bit ahead of the students' current competence, giving helpful assistance whenever the students face insurmountable difficulties, and confer meaningful feedback wherever necessary, whereas at the same time the students are also held responsible for their own learning and get actively involved in the learning process. Vygotsky (1978) claims that:

an essential feature of learning is that it creates the zone of proximal development; that is, learning awakens a variety of internal developmental processes that are able to operate only when the [learner] is interacting with people in his environment and in cooperation with his peers. Once these processes are internalized, they become part of the [learner's] independent developmental achievement. (p. 90)

So, during the instructional process, the teacher is highly expected to involve the learners in constructing their learning. They may do so by giving problems to solve and also by providing assistance and guidance. It is important that during the process of instruction, therefore, teacher is neither to dominate nor to leave the process.

\subsection{Linguistic Factors}

Regarding to both the learning and teaching (instructional) process is the type of language samples exposed to the students. In many cases, the instructions of English grammar as seen from the students' reports mostly dealt with decontextualised sentences whose focus was mostly on the accuracy of using particular grammatical forms. Less or no attention was specifically devoted to the meaning or functions attached to the forms, especially as used in communicative contexts. Similarly, the emphasis of grammar instruction was mostly on rules. As such, some of the students develop beliefs that grammar is associated with rules to be mastered or even to be memorised only. 
Following the new era of teaching grammar nowadays, however, it is important that teachers employ authentic texts bearing clear usage of grammatical forms, meaning, and functions and thus avoid teaching grammatical forms as discrete points whatsoever (Larsen-Freeman, 2001; Celce-Murcia, 2002; Ellis, 2006; Nassaji \& Fotos, 2004, 2011). Thus, the teaching of grammar should be more descriptive rather than prescriptive in nature, since through the teaching of grammar from the perspective of how the speakers actually use the language rather than how they should use the language will then the students understand and be able to use the language both accurately and appropriately. Also, descriptive grammar teaching, i.e. the teaching of grammar which is authentic on the basis of how it is actually used in both formal and informal discourse, can to a great extent be perceived motivating by the learners (See Gilmore, 2007, for a review).

\section{Conclusion and Teaching Implications}

Referring back to the problems of the study, it can be concluded that the group of Indonesian students' mastery of tenses and aspects as part of their mastery of English grammar is still low. The length of instructions the students experienced and their having perception that studying English grammar is important apparently do not shape their grammar mastery. Based on the analysis of the students' responses in the interview, however, their habits in learning are apparently more related to their improved or unimproved mastery. In addition, the modes of instruction and the type of language used to provide the students with the examples of particular topics of grammar apparently also constitute supportive or less supportive factors to the students' improved or unimproved mastery as well.

As regards the latter, it is important that the teachers of English grammar be mindful about the way they employ in teaching grammar. It is suggested that effective grammar teaching is the one which engages the students' in the process of conceptualisation of grammatical forms, meaning and functions as embedded in authentic discourse. Further, the teachers are also expected to facilitate the students' learning, i.e. neither to dominate nor to leave the process.

Acknowledgements: The authors would like to thank Pak Henri Fatkurochman, Fitria Rahmawati and Ibu Pratiwi Andriani who helped proctor and administer the test to the students.

\section{References}

Allen, W. S. (1974). Living English structure. London: Longman.

Andrews, S. J. (1997). Metalinguistic awareness and teacher explanation. Language Awareness, 6(2\&3), $147-61$. http://dx.doi.org/10.1080/09658416.1997.9959924

Andrews, S. (2003). Teacher language awareness and the professional knowledge base of the L2 teacher. Language Awareness, 12(2), 81-95. http://dx.doi.org/10.1080/09658410308667068

Azar, B. S. (1992). Understanding and using English grammar. Upper Saddle River, NJ: Prentice-Hall, Inc.

Canale, M. (1983). From communicative competence to communicative language pedagogy. In J. C. Richards \& R. Schmidt (Eds.), Language and Communication (pp.2-27). London: Longman.

Canale, M. \& Swain, M. (1980). Theoretical bases of communicative approaches to second language teaching and testing. Applied Linguistics, 1, 1-47. http://dx.doi.org/10.1093/applin/I.1.1

Celce-Murcia, M. (2002). Why it makes sense to teach grammar in context through discourse. In E. Hinkel and S. Fotos (Eds.), New Perspectives on Grammar Teaching in Second Language Classrooms, (pp. 119-133). New York: Routledge.

Downing, A. \& Locke, P. (2006). English grammar: A university course (2 $2^{\text {nd }}$ ed.). Abingdon, Oxon: Routledge.

Eastwood, J. (1994). Oxford guide to English grammar. Oxford: Oxford University Press.

Ellis, R. (2006). Current Issues in the Teaching of Grammar: An SLA Perspective. TESOL Quarterly, 40(1): 83-107. http://dx.doi.org/10.2307/40264512

Ellis, R., Sheen, Y., Murakami, M., \& Takashima, H. (2008). The effect of focused and unfocused written corrective feedback in an English as a foreign language context. System, 36, 353-371.

http://dx.doi.org/10.1016/j.system.2008.02.001

Gilmore, A. (2007). Authentic materials and authenticity in foreign language learning. Language Teaching, 40(2): 97118. http://dx.doi.org/10.1017/S0261444807004144

Harley, B., \& Swain, M. (1984). The interlanguage of immersion students and its implications for second language teaching. In A. Davies, C. Criper, \& A. P. R. Howatt (Eds.), Interlanguage (pp. 291-311). Edinburgh: Edinburgh University Press.

Hewings, M. (1999). Advanced grammar in use: A self-study reference and practice book for advanced learners of English. Cambridge: Cambridge University Press.

Holec, H. (1981). Autonomy in foreign language learning. Strasbourg: Council of Europe.

Huddleston, R. \& Pullum, G.K. (2005). A student's introduction to English grammar. New York: Cambridge University Press. 
Hughes, R. \& McCarthy, M. (1998). From sentence to discourse: Discourse grammar and English language teaching. TESOL Quarterly, 32(2), 263-287. http://dx.doi.org/10.2307/3587584

Kellerman, E. (1995). Cross-linguistic influence: Tansfer to nowhere? Annual Review of Applied Linguistics, 15, 125150. http://dx.doi.org/10.1017/S0267190500002658

Kellerman, E., \& Sharwood-Smith, M. (1986). Cross-linguistic influence in second language acquisition. New York: Pergamon Press.

Kohonen, V. (1992). Experential language learning: Second language learning as cooperative learner education. In D. Nunan (Ed.), Collaborative language learning and teaching (pp. 14-39). New York: Cambridge University Press.

Kolb, D. (1984). Experential learning: Experience as the source of learning and development. Englewood Cliffs, N.J.: Prentice-Hall.

Lapkin, S., Hart, D., \& Swain, M. (1991). Early and middle French immersion programs: French-language outcomes. Canadian Modern Language Review, 48, 11-40.

Larsen-Freeman, D. (2001). Teaching grammar. In M. Celce-Murcia (Ed.), Teaching English as a second or foreign language ( $3^{\text {rd }}$ Ed.) (pp. 251-266). Boston, MA: Heinle \& Heinle.

Lightbown, P. M., \& Spada, N. (1999). How languages are learned. Oxford: Oxford University Press.

Little, D. (1999). Learner autonomy is more than a Western cultural construct. In S. Cotterall and D. Crabbe (Eds.), Learner Autonomy in Language Learning: Defining the Field and Effecting Change (pp. 11-18). Frankfurt am Main: Lang.

Lado, R. (1957). Linguistic across cultures. Ann-Arbor: University of Michigan Press.

Murphy, R. (1989). English grammar in use. New York: Cambridge University Press.

Nassaji, H. \& Fotos, S. (2004). Current developments in research on the teaching of grammar. Annual Review of Applied Linguistics, 24, 126-145. http://dx.doi.org/10.1017/S0267190504000066

Nassaji, H. \& Fotos, S. (2011). Teaching Grammar in Second Language Classrooms: Integrating Form-Focused Instruction in Communicative Context. New York: Routledge.

Odlin, T. (2003). Cross-linguistic influence. In C. Doughty \& M. Long (Eds.), The handbook of second language acquisition (h. 436-386). Malden, MA: Blackwell Publishing.

Oxford, R. L. (2008). Hero with a thousand faces: learner autonomy, learning strategies and learning tactics in independent language learning. In S. Hurd and T. Lewis (Eds.), Language Learning Strategies in Independent Settings (pp. 41-63). Bristol, Bufallo, Toronto: Multilingual Matters.

Richards, J. C. \& Renandya, W. A. (2002). Methodology in language teaching: An anthology of current practice. Cambridge: Cambridge University Press.

Ringbom, H. (2007). Cross-linguistic similarity in foreign language learning. Clevedon, Buffalo, Toronto: Multilingual Matters Ltd.

Savignon, S. (2005). Communicative language teaching: Strategies and goals. In E. Hinkel (Ed.), Handbook on research in second language teaching and learning (pp. 635-51). Mahwah, NJ: Lawrence Erlbaum Associates.

Schmidt, R. W. (1990). The role of consciousness in second language learning. Applied Linguistics, 11(2), $129-158$. http://dx.doi.org/10.1093/applin/11.2.129

Schmidt, R. W. (1993). Awareness and second language acquisition. Annual Review of Applied Linguistics, 13, 206226. http://dx.doi.org/10.1017/S0267190500002476

Shulman, L. (1987). Knowledge and teaching: Foundations of the new reform. Harvard Educational Review, 57(1), 122. http://dx.doi.org/10.17763/haer.57.1.j463w79r56455411

Swain, M. (1985). Communicative competence: Some rules of comprehensible input and comprehensible output in its development. In S. Gass, \& C. Madden (Eds.), Input in second language acquisition (pp. 235-53). Rowley, MA: Newbury House.

Terrell, T. D., (1991). The role of grammar instruction in a communicative approach. The Modern Language Journal, 75(1), 53-63. http://dx.doi.org/10.1111/j.1540-4781.1991.tb01083.x

Vygotsky, L. S. (1978). Mind in Society: The development of higher psychological processes. In M. Cole, V. JohnSteiner, S. Scribner, \& E. Souberman (Eds.). Cambridge, MA: Harvard University Press.

Whitman, R. L., \& Jackson, K. L. (2006). The unpredictability of contrastive analysis. Language Learning, 22(1), 2941. http://dx.doi.org/10.1111/j.1467-1770.1972.tb00071.x 